S. R. Teixeira, A. E. Souza, C. L. Carvalho, V.C.S. Reynoso, M. Romero, J. Ma. Rincón, Characterization of a wollastonite glass-ceramic material prepared using sugar cane bagasse ash (SCBA) as one of the raw materials. Materials Characterization Volume 98, December 2014, Pages 209-214; doi:10.1016/j.matchar.2014.11.003

\title{
Characterization of a wollastonite glass-ceramic material prepared using sugar cane bagasse ash (SCBA) as one of the raw materials
}

- Silvio R. Teixeira ${ }^{\mathrm{a},}$, Agda E. Souza ${ }^{\mathrm{a}}$, Claudio L. Carvalho ${ }^{\mathrm{b}}$, Victor C.S. Reynoso ${ }^{\mathrm{b}}$, Maximina Romero $^{\mathrm{c}}$, Jesús Ma. Rincón ${ }^{\mathrm{c}}$

${ }^{\text {a }}$ Universidade Estadual Paulista — UNESP, Faculdade de Ciências e Tecnologia — FCT, 19060-900 Presidente Prudente — SP, Brazil

${ }^{\mathrm{b}}$ Universidade Estadual Paulista — UNESP, Faculdade de Engenharia de Ilha Solteira — FEIS, 15385-000 Ilha Solteira - SP, Brazil

${ }^{\mathrm{c}}$ Instituto de Ciencias de la Construccion Eduardo Torroja - IETCC, CSIC, 28033 Madrid, Spain

\begin{abstract}
Glass-ceramic material prepared with sugar cane bagasse ash as one of the raw materials was characterized to determine some important properties for its application as a coating material. $\mathrm{X}$-ray diffraction patterns showed that wollastonite- $2 \mathrm{M}\left(\mathrm{CaSiO}_{3}\right)$ was the major glass-ceramic phase. The Rietveld method was used to quantify the crystalline (60 wt.\%) and vitreous (40 wt.\%) phases in the glass-ceramic. The microstructure (determined by scanning electron microscopy) of this material had a marble appearance, showing a microporous network of elongated crystals with some areas with dendritic, feather-like ordering. Microhardness data gave a mean hardness value of 564.4 HV (Vickers-hardness), and light microscopy disclosed a greenish brown colored material with a vitreous luster.
\end{abstract}

\section{Keywords}

Glass-ceramics; Wollastonite; Sugarcane; Ash; Hardness; X-ray diffraction

\section{Introduction}

Glass-ceramic materials with wollastonite as the main crystalline phase are produced from glasses of the $\mathrm{SiO}_{2}-\mathrm{Al}_{2} \mathrm{O}_{3}-\mathrm{CaO}$ system by controlled surface crystallization, where conventional nucleating agents such as $\mathrm{TiO}_{2}$ and $\mathrm{ZrO}_{2}$, are used in the process. Such glassy materials show special visual effects and other important properties (hardness greater than that of natural stones, zero water absorption, lower density, etc.). They are produced on a large scale and used as coatings (floors and inside and outside walls) in building construction. One of the 
S. R. Teixeira, A. E. Souza, C. L. Carvalho, V.C.S. Reynoso, M. Romero, J. Ma. Rincón, Characterization of a wollastonite glass-ceramic material prepared using sugar cane bagasse ash (SCBA) as one of the raw materials. Materials Characterization Volume 98, December 2014, Pages 209-214; doi:10.1016/j.matchar.2014.11.003

most important wollastonite glass-ceramic for applications in the construction industry is produced by the Japanese company "Nippon Electric Glass" with the name Neoparis ${ }^{\circledR}$. A major advantage of this material, in relation to natural stones, is that large flat and curved panels can be produced. Glass crystallization starts at temperatures above $950{ }^{\circ} \mathrm{C}$, forming first wollastonite (triclinic, Tc) by surface crystallization. At $1000{ }^{\circ} \mathrm{C}$, alpha-wollastonite (monoclinic) grows in a needlelike form from the surface of the glass towards the interior of the glass grain, making the material look like granite or marble due to the differences in light diffraction indices between the crystals and glassy matrix. At $1200{ }^{\circ} \mathrm{C}$, beta-wollastonite is produced (monoclinic, pseudo-wollastonite) which shows a granular crystallographic morphology with more opaque crystals [1].

Three different wollastonite (calcium monosilicate) modifications are known: wollastonite (triclinic at ambient temperature), alpha-wollastonite (also 2M, monoclinic or parawollastonite) and beta-wollastonite (also 4A or pseudo- or cyclo-wollastonite), where both monoclinic forms are produced at higher temperatures [2]. Wollastonite appears only in masses of glass cooled slowly from $1120{ }^{\circ} \mathrm{C}$ in the form of spheres or large-sized crystalline aggregates. The second one is formed after heating at high temperatures as needles, prisms or ribbons and remains metastable in glassy matrices.

Industrial waste, slag ash, or fly ash is used as raw material in the ceramic industry [3], [4], [5], [6] and [7] and for glass-ceramic production [1], [8], [9], [10] and [11] in different countries. This process depends on additives and waste composition, which in general, contains numerous secondary components and impurities. The interest in sugar cane bagasse ash (SCBA) is due to its composition, the huge volume that is produced in Brazil (> 3 million tons/year) and the prospect of increased production in the coming years to produce alcohol for use as vehicle fuel [12]. Nowadays, the construction industry consumes very large amounts of natural stone (granite and marble) coating. Glass-ceramics have important properties that outweigh those of natural stones, for example, high wear resistance, greater hardness, zero water absorption, easily shaped (curved panels or other forms), among others. Besides their usefulness to the construction industry, the use of glass-ceramics decreases the exploitation of natural stone reserves and decreases environmental impacts. The use of SCBA as one of the raw materials to produce glass-ceramic materials is a pioneer project, and there are few data regarding this. Since SCBA was the focus of this study, throughout this paper, the term SCBA glass-ceramic designates the final product obtained from it, mixed with different carbonates. 
S. R. Teixeira, A. E. Souza, C. L. Carvalho, V.C.S. Reynoso, M. Romero, J. Ma. Rincón, Characterization of a wollastonite glass-ceramic material prepared using sugar cane bagasse ash (SCBA) as one of the raw materials. Materials Characterization Volume 98, December 2014, Pages 209-214; doi:10.1016/j.matchar.2014.11.003

The kinetics of glass-ceramic formation through crystallization of glass using SCBA was studied in a previous work [8], and in a recent publication [9], we showed the viability of producing glass-ceramic material using SCBA and a widely available material (limestone). In this paper, glass-ceramic material was characterized by using $\mathrm{X}$-ray diffraction and fluorescence, thermal analysis and hardness measuring techniques. The microstructure of the glass-ceramic material was evaluated by scanning electron microscopy (SEM), and the percentages of the crystalline and amorphous phases, which influence the properties of glassceramic materials, were determined by the Rietveld method, using a standard with known crystalline and amorphous fractions.

\section{Materials and methods}

The material studied was bottom ash collected under the boilers in an ethanol/sugar plant in Presidente Prudente County, Brazil. This ash is produced during the burning of bagasse to produce steam and electricity in the boilers of the company [12].

The ash was characterized using X-ray fluorescence (model XRF-1800, Shimadzu Corporation, Kyoto, Japan) and X-ray diffraction (model XRD-6000, Shimadzu) to determine its chemical composition and the main crystalline phases, respectively.

The glass composition was determined using a ternary phase diagram, according to the composition of the ash, the desired final crystalline phase and the calculated melting temperature. The theoretical melting temperature of the composition for production of the silicate glass was calculated using the method proposed by Chengyu and Ying [13]. The ash was mixed with different amounts of $\mathrm{MgO}$ and $\mathrm{Na}_{2} \mathrm{O}$. Among the compositions studied, allowing for the fusion at temperatures lower than $1450{ }^{\circ} \mathrm{C}$, the combination of ash (50 wt.\%) with calcium (45 wt.\%) and sodium (5 wt.\%) oxides provided a theoretical melting temperature around $1340{ }^{\circ} \mathrm{C}$. The components of the glass were mixed, homogenized and melted (heated at $20{ }^{\circ} \mathrm{C} / \mathrm{min}$ ) to $1450{ }^{\circ} \mathrm{C}$ and held at this temperature for $1 \mathrm{~h}$. The melt was poured into an aluminum container with distilled water to cool quickly (quenching), minimizing the possibility of crystallization (melt-quenching method). This glass is referred to as V1 below.

Glass V1 was ground to $60 \mu \mathrm{m}$ with a normal particle size distribution and analyzed by XRD to see if there was crystallization during the cooling process and by XRF to determine its chemical composition. Part of the glass powder was heat treated using thermal analysis equipment (model Labsys Thermal Analyzer, Setaram Instrumentation, France) up to $1400{ }^{\circ} \mathrm{C}$ at a rate of $50{ }^{\circ} \mathrm{C} / \mathrm{min}$ to determine glass transition, crystallization and fusion temperatures. 
S. R. Teixeira, A. E. Souza, C. L. Carvalho, V.C.S. Reynoso, M. Romero, J. Ma. Rincón, Characterization of a wollastonite glass-ceramic material prepared using sugar cane bagasse ash (SCBA) as one of the raw materials. Materials Characterization Volume 98, December 2014, Pages 209-214; doi:10.1016/j.matchar.2014.11.003

Another part of the glass powder was crystallized from poured powder at a heating rate of 50 ${ }^{\circ} \mathrm{C} /$ min and kept as a powder in a crucible for $1 \mathrm{~h}$ at the crystallization peak temperature (1050 ${ }^{\circ} \mathrm{C}$ ), and afterwards, it was ground and analyzed by XRD to identify the phases formed in the glass-ceramic material. Scanning electron microscopy (SEM model XL 30, Philips, Netherlands) was used to examine the morphology of the crystallized phases on the surface of a sample etched with HF.

To determine sample hardness, a piece of sample was placed in a steel cylinder, glued with Araldite ${ }^{\circledR}$ and polished with sandpapers: $\mathrm{P} \# 600(25.8 \mu \mathrm{m})$ to \#2400 (9.2 $\left.\mu \mathrm{m}\right)$. After preparation, samples were placed in the micro-hardness testing machine, and 10 measurements were taken at different positions to obtain an average value. The test was performed with a micro-hardness tester (model HMV 2000, Shimadzu) equipped with a diamond penetrator tip (square pyramid base) for Vickers hardness testing, using a 2.492-N load for $15 \mathrm{~s}$.

To quantify the phases in the glass-ceramic material, a standard sample was prepared using glass powder (the glass-ceramic precursor) and crystalline silicon powder (XRD Shimadzu standard). A known amount of the standard was mixed with the glass-ceramic sample to form a new composite sample, resulting in the following final composition: $6.4 \mathrm{wt} . \%$ powdered V1 glass (the glass-ceramic precursor), $14.7 \mathrm{wt} \%$ powdered silicon standard and $78.97 \mathrm{wt} \%$ powdered glass-ceramic sample. The software GSAS (General Structure Analysis System) [14] was used to fit the XRD data and to determine the concentrations of crystalline phases. These data were used to estimate the amorphous concentration in the glass-ceramic material. Spectra were collected using $\mathrm{Cu} \mathrm{K} \alpha$ radiation and a graphite monochromator in the diffracted beam, from 5 to $105^{\circ}, 2 \theta$ range. The scanning step and time/step were $0.02^{\circ}$ and $6 \mathrm{~s}$, respectively, using D0.5 and S0.5 divergence and scattering slits.

\section{Results and discussion}

\subsection{Chemical analysis}

Table 1 provides the results of the chemical analysis by X-ray fluorescence (oxides wt.\%) of SCBA and glass V1. The chemical composition of glass V1 melted from $\mathrm{Na}_{2} \mathrm{O}$ (5 wt.\%)-CaO (45 wt.\%)-ash (50 wt.\%) showed that there was a contamination of the glass with aluminum from the alumina crucible during the glass melting. This glass was greenish due to presence of iron in the ash [8]. 
S. R. Teixeira, A. E. Souza, C. L. Carvalho, V.C.S. Reynoso, M. Romero, J. Ma. Rincón, Characterization of a wollastonite glass-ceramic material prepared using sugar cane bagasse ash (SCBA) as one of the raw materials. Materials Characterization Volume 98, December 2014, Pages 209-214; doi:10.1016/j.matchar.2014.11.003

Table 1. Chemical composition and stoichiometric composition of phases given as reference in the glass-ceramic material measured by X-ray fluorescence (XRF).

\begin{tabular}{lllllll}
\hline & & $\begin{array}{l}\text { Reduced V1 } \\
\text { Glass } \\
\text { precursors }\end{array}$ & $\begin{array}{l}\text { Stoichiometric } \\
\text { composition } \\
\text { wollastonite } \\
\text { (as reference) }\end{array}$ & $\begin{array}{l}\text { Stoichiometric } \\
\text { gehlenite (as } \\
\text { reference) }\end{array}$ & $\begin{array}{l}\text { Nepheline- } \\
\text { sienite (as } \\
\text { reference) }\end{array}$ \\
\hline $\mathrm{Na}_{2} \mathrm{O}$ & - & 2.97 & 3.08 & - & - & 15.92 \\
$\mathrm{~K} 2$ & 2.04 & 0.69 & - & - & - & 8.05 \\
$\mathrm{CaO}$ & 0.67 & 31.17 & 32.36 & 48.28 & 20.0 & - \\
$\mathrm{MgO}$ & 1.56 & 0.80 & - & - & - & - \\
$\mathrm{Al}_{2} \mathrm{O}_{3}$ & 1.46 & 9.18 & 9.53 & - & 36.7 & 34.93 \\
$\mathrm{SiO}_{2}$ & 91.53 & 52.99 & 55.02 & 51.72 & 43.20 & 41.10 \\
$\mathrm{TiO}_{2}$ & 0.23 & 0.31 & - & - & - & - \\
$\mathrm{Fe}_{2} \mathrm{O}_{3}$ & 0.91 & 0.89 & - & - & - & - \\
$\mathrm{Cr}_{2} \mathrm{O}_{3}$ & 0.06 & 0.09 & - & - & - & - \\
$\mathrm{P}_{2} \mathrm{O}_{5}$ & 1.50 & 0.35 & - & - & - & - \\
$\mathrm{SO}_{2}$ & 0.05 & 0.55 & - & - & - & - \\
\hline
\end{tabular}

\subsection{Characterization of glass and glass-ceramic material}

X-ray diffraction analysis of V1 glass quenched in air (Fig. 1) did not indicate the presence of crystalline phases, showing only the characteristic band of amorphous material around the Bragg position $2 \theta=30^{\circ}$.

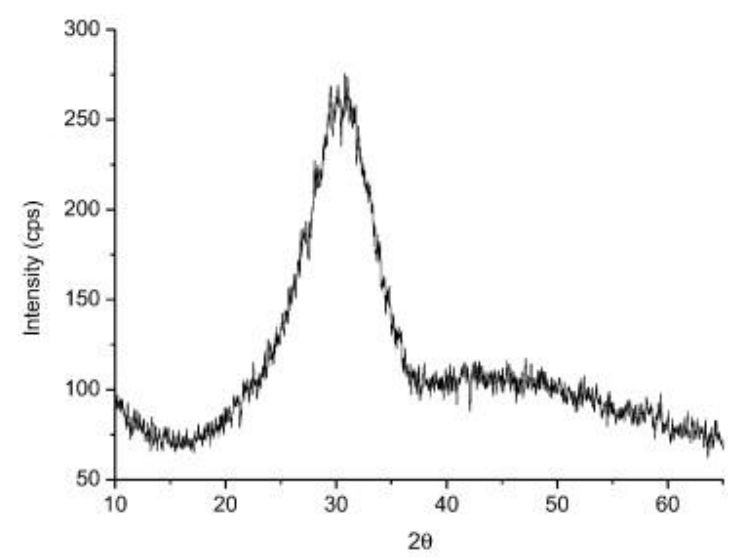

Fig. 1. X-ray diffractogram of the V1 glass (Bragg angle, 20).

Differential thermal analysis (DTA) (Fig. 2, heating rate of $50{ }^{\circ} \mathrm{C} / \mathrm{min}$ ) showed a glass transition temperature (Tg) of glass $\mathrm{V} 1$ at around $736{ }^{\circ} \mathrm{C}$. The main crystallization peak (Tc) can be seen at $1052{ }^{\circ} \mathrm{C}$ and a melting peak (Tm) at $1349{ }^{\circ} \mathrm{C}$. The peaks at $1173{ }^{\circ} \mathrm{C}$ and $1305{ }^{\circ} \mathrm{C}$ indicated the crystallization (Tc) of the glassy phase forming new phases. After DTA, the 
S. R. Teixeira, A. E. Souza, C. L. Carvalho, V.C.S. Reynoso, M. Romero, J. Ma. Rincón, Characterization of a wollastonite glass-ceramic material prepared using sugar cane bagasse ash (SCBA) as one of the raw materials. Materials Characterization Volume 98, December 2014, Pages 209-214; doi:10.1016/j.matchar.2014.11.003

original glass powder (ground and sieved at $60 \mu \mathrm{m}$ ) was crystallized at $1050{ }^{\circ} \mathrm{C}$ for $1 \mathrm{~h}$, at a heating rate of $50{ }^{\circ} \mathrm{C} / \mathrm{min}$ in a platinum crucible. The glass-ceramic obtained had a greenish brown color and it was very hard and difficult mill to grind. Part of this glass ceramic was ground using a manual tungsten carbide mill (mortar), and analyzed by X-ray diffraction.

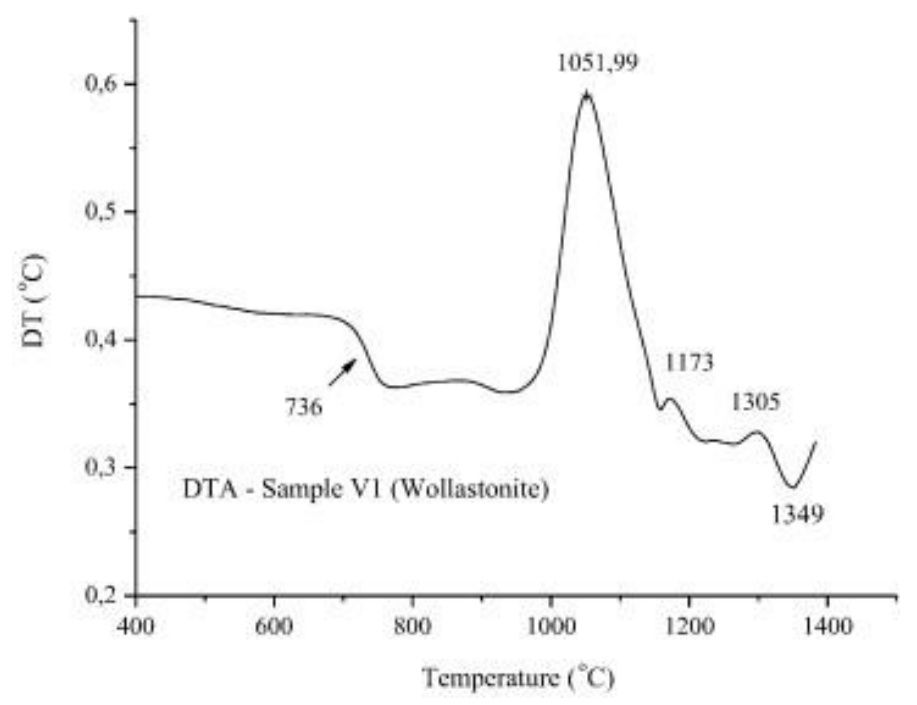

Fig. 2. Differential thermal analysis data $\left(50^{\circ} \mathrm{C} / \mathrm{min}\right)$ of the original V1 glass showing the temperatures of: glass transition (arrow), three crystallization peaks and the melting temperature.

X-ray diffraction analysis of the glass-ceramic material (Fig. 3) showed that the wollastonite$2 \mathrm{M}$, a monoclinic (or parawollastonite) phase of high temperature, $\mathrm{CaSiO}_{3}$ ( $\mathrm{PDF} 43-1460$ ) was the major crystalline phase. Also, some peaks of nepheline (PDF 71-0954) and of gehlenite (PDF 74-1607) were identified. A broad band around $30^{\circ}(2 \theta)$ confirmed the amorphous fraction (glass) in the sample (inset Fig. 3 and Fig. 6). Due to the complex composition of the ash, it is possible that there were some other silicates with short-range order that could not be identified by X-ray diffraction and that contributed to the amorphous band intensity. In Fig. 2 (DTA), the main exothermic peak (around $1052{ }^{\circ} \mathrm{C}$ ) is broad suggesting that the crystallization of these phases was simultaneous and/or involved much closer sequential processes. A glassceramic material may be highly crystalline or may contain substantial residual glass [1]. Someof the glass-ceramic properties are associated with this combination, which may give them special and unique microstructures. 
S. R. Teixeira, A. E. Souza, C. L. Carvalho, V.C.S. Reynoso, M. Romero, J. Ma. Rincón, Characterization of a wollastonite glass-ceramic material prepared using sugar cane bagasse ash (SCBA) as one of the raw materials. Materials Characterization Volume 98, December 2014, Pages 209-214; doi:10.1016/j.matchar.2014.11.003

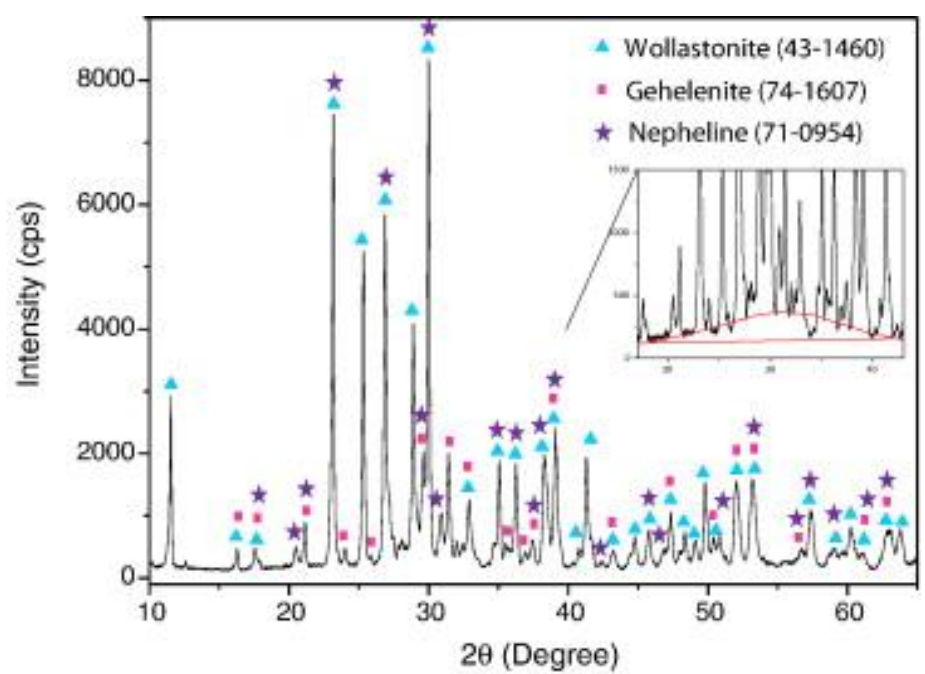

Fig. 3. X-ray pattern of glass-ceramic material V1 shows alpha-wollastonite (2M) as the major phase. Nepheline and gehlenite are the other identified phases.

Microhardness data are shown in Table 2. These values were measured at 10 different points on the sample giving a mean value of: HV $564 \pm 34$ or $(5.6 \pm 0.5 \mathrm{GPa}$ ) (about 5.2 on Mohs' scale). This hardness value was similar to that known for silicates (Mohs' scale) formed during crystallization of this glass: wollastonite (4.5 to 5.0), gehlenite (5 to 6), nepheline (5.5 to 6.0) and window glass plate (around 5.5). Natural stones, such as granite and marble, have a Mohs hardness of around 6 and 4, respectively (Table 3) [15] and [16].

Table 2. Hardness Vickers (HV<comma> GPa) in glass-ceramic V1.

\begin{tabular}{ll}
\hline Points & HV \\
\hline 1 & 54 \\
2 & 594 \\
3 & 537 \\
4 & 552 \\
5 & 611 \\
6 & 58 \\
7 & 517 \\
8 & 6 \\
9 & 586 \\
10 & 527 \\
Average (HV) & 564.4 \\
Average (GPa) & 5.64 \\
\hline
\end{tabular}


S. R. Teixeira, A. E. Souza, C. L. Carvalho, V.C.S. Reynoso, M. Romero, J. Ma. Rincón, Characterization of a wollastonite glass-ceramic material prepared using sugar cane bagasse ash (SCBA) as one of the raw materials. Materials Characterization Volume 98, December 2014, Pages 209-214; doi:10.1016/j.matchar.2014.11.003

Table 3. Comparative values of hardness and microhardness for different inorganic materials.

\begin{tabular}{lll}
\hline Material & $\begin{array}{l}\text { Vickers microhardness } \\
(\mathrm{GPa})\end{array}$ & $\begin{array}{l}\text { Mohs' scale (according to } \\
\text { references) }\end{array}$ \\
\hline SCBA glass-ceramic & 5.44 (this work) & 6 \\
Marble & $0.70 \mathrm{a}$ & $3.7-4.3 \mathrm{a} 4 \mathrm{~b}$ \\
Granite & $7.00 \mathrm{a}$ & $5.8-7.2 \mathrm{a} 6 \mathrm{~b}$ \\
Basalt & $10.00 \mathrm{a}$ & $4.8-6.5 \mathrm{a}$ \\
Pyrex glass & $5.95 \mathrm{a}$ & $5 \mathrm{~b}$ \\
Neoparis & & $6 \mathrm{a}$ \\
Glass-ceramic glazesFe $\mathrm{O}_{3}$ enriched & $6.4 \mathrm{c}$ & - \\
Porcelainized stoneware & - & $5-6 \mathrm{a}$ \\
\hline
\end{tabular}

The sample under optical microscopy (Fig. 4) looked like it was fully melted, but the sample's morphology showed an irregular surface, not characteristic of melted material. The polished surface makes the material look like polished marble. Besides the hardness and the brightness (when polished), glass-ceramics have other properties that may be superior to those of natural stones.
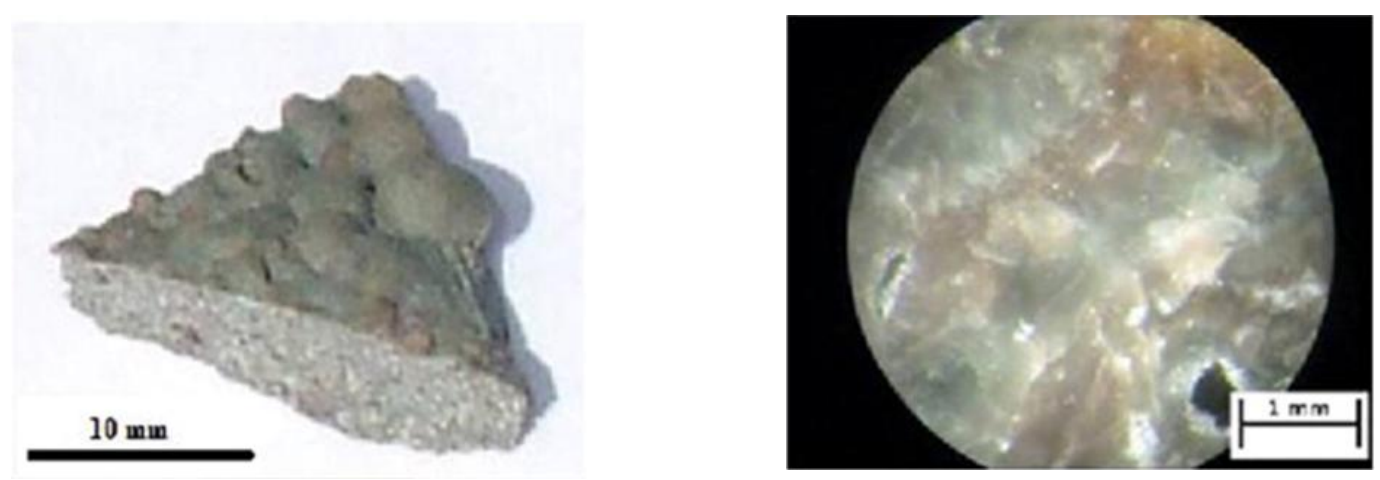

Fig. 4. Glass-ceramic V1 before and after polishing (single view and optical microscopies).

\subsection{Scanning electron microscopy (SEM)}

Fig. 5a-d shows the microstructure of the glass-ceramic material produced from V1 glass after thermal treatment at $1050{ }^{\circ} \mathrm{C}$ for $1 \mathrm{~h}$. The microstructure of this sintered wollastonite glass-ceramics was quite heterogeneous, showing rounded areas mixed with structured areas of porosity with elongated crystals like carpeted skin tissue. The grain boundaries of original 
S. R. Teixeira, A. E. Souza, C. L. Carvalho, V.C.S. Reynoso, M. Romero, J. Ma. Rincón, Characterization of a wollastonite glass-ceramic material prepared using sugar cane bagasse ash (SCBA) as one of the raw materials. Materials Characterization Volume 98, December 2014, Pages 209-214; doi:10.1016/j.matchar.2014.11.003

particles were not clearly evident. However, it seemed that some areas were rounded and totally crystallized, mixed with other irregular and/or pseudo-polygonal areas.

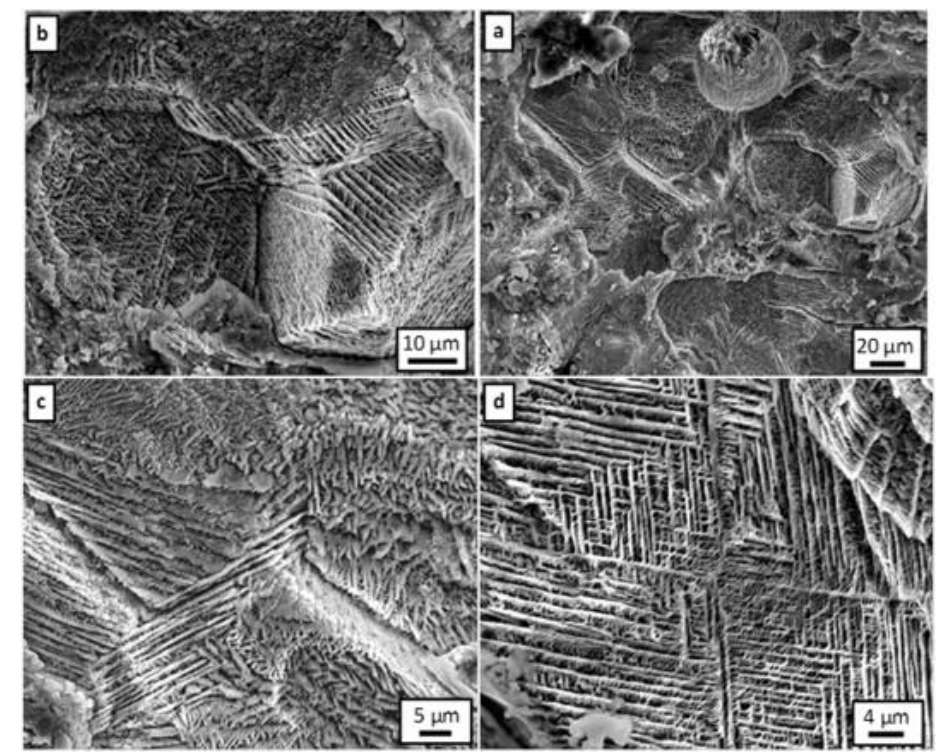

Fig. 5. SEM images of V1 glass-ceramic obtained by heating at $1050^{\circ} \mathrm{C}$ for $1 \mathrm{~h}$.

On the other hand, these SEM observations showed that wollastonite crystallization leads to a dendritic microstructure, in which crystals grow preferably in one axial direction and sporadically diverge into short branches (Fig. 5d). The dendritic growth in some areas also showed feather-like microstructure with dendritic axes not well developed. The crystalline phase appeared as a compact network of interlocking acicular crystals, and the glassy phase filled the interstices between crystals. The observed dendritic growth indicates a fast formation of wollastonite crystals. When glass devitrifies, there is an exchange of its inner free energy with the liquid phase, if the temperature gradient between the crystal and the surrounding glass is high enough, diffusion appears as the mechanism of energy transfer. Since this type of heat exchange needs a large surface, the interface between the liquid phases and the crystal changes from a planar to a columnar shape, giving rise to a dendritic structure [17].

\subsection{Concentration of crystalline and amorphous phases}

The Rietveld method was applied to analyze the XRD data of the composite (glass-ceramic), which had unknown percentages of crystalline and amorphous phases. Nowadays, the Rietveld method is usually used for quantitative determination of phases in glass-ceramics [18], [19] and [20]. The fitting is plotted in Fig. 6, and the quantitative fractions are given in Table 4. The refining parameters were: $\chi^{2}$ (3.776), Rwp (0.0952) and R(F2) (0.0539), where $\chi^{2}$ represents 
S. R. Teixeira, A. E. Souza, C. L. Carvalho, V.C.S. Reynoso, M. Romero, J. Ma. Rincón, Characterization of a wollastonite glass-ceramic material prepared using sugar cane bagasse ash (SCBA) as one of the raw materials. Materials Characterization Volume 98, December 2014, Pages 209-214; doi:10.1016/j.matchar.2014.11.003

goodness of fit of parameter refinement, Rwp indicates the success of the refinement, and $\mathrm{R}(\mathrm{F} 2)$, or R-Bragg, is the crystallographic model to fit the experimental data. The values obtained for these parameters indicated a good fit of the theoretical model to the experimental data. The structure refining showed that the crystalline fraction $(60 \%)$ was predominant in this glass-ceramic material and confirmed that wollastonite (34\%) was the major crystalline phase.

Table 4. Concentrations of the crystalline and amorphous phases in the glass-ceramic.

\begin{tabular}{lll}
\hline Phase & & \\
& & Fraction (\%) \\
\hline Wollastonite & $\mathrm{CaSiO}_{3}$ & 34 \\
Gehlenite & $\mathrm{Ca}_{2} \mathrm{Al}_{2} \mathrm{SiO}_{7}$ & 11 \\
Nepheline & $\mathrm{Na}-\mathrm{K}-\mathrm{Ca}-\mathrm{Al}$ silicate & 15 \\
Amorphous & Silicate-glass & 40 \\
\hline
\end{tabular}

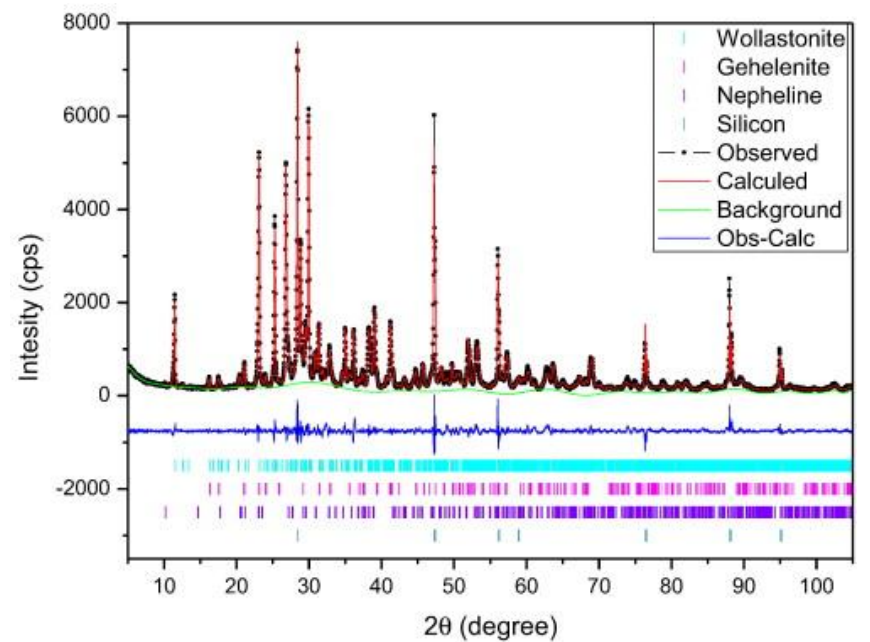

Fig. 6. Results of the Rietveld adjustment to the XRD data from V1 glass-ceramic.

By locating the composition of the original glass prepared using SCBA in the ternary system $\mathrm{CaO}-\mathrm{Al}_{2} \mathrm{O}_{3}-\mathrm{SiO}_{2}$ (Fig. 7), it can be seen that the composition was reduced to these three components inside the pseudowollastonite phase region and nearer to the anorthite region than gehlenite phase [1]. It is believed that due to the alkaline content $\left(\mathrm{Na}_{2} \mathrm{O}\right.$ and $\left.\mathrm{K}_{2} \mathrm{O}\right)$, as well as $\mathrm{Fe}_{2} \mathrm{O}_{3}$ and some nucleating agents coming from the SCBA waste, the "reduced ternary composition" can move to lower temperatures, making this glass closer to the wollastonitegehlenite region, favoring the formation of nepheline and facilitating the crystal growth of the 
S. R. Teixeira, A. E. Souza, C. L. Carvalho, V.C.S. Reynoso, M. Romero, J. Ma. Rincón, Characterization of a wollastonite glass-ceramic material prepared using sugar cane bagasse ash (SCBA) as one of the raw materials. Materials Characterization Volume 98, December 2014, Pages 209-214; doi:10.1016/j.matchar.2014.11.003

major crystalline phases identified by XRD in this glass. The several impurities in the ash, which were involved in the nucleation and crystallization processes, fostered a complex heterogeneous nucleation process.

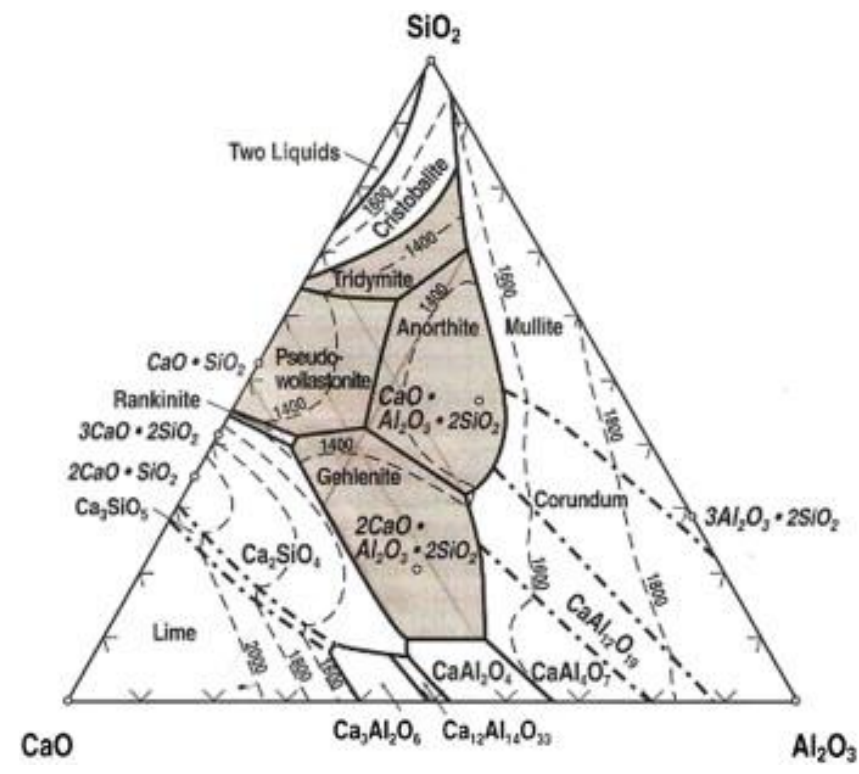

Fig. 7. Ternary phase diagram of the $\mathrm{CaO}-\mathrm{Al}_{2} \mathrm{O}_{3}-\mathrm{SiO}_{2}$ base system [1].

\section{Conclusions}

The glass-ceramic material produced using SCBA had the appearance of marble and contained wollastonite $\left(\mathrm{CaSiO}_{3}\right)$ as the major crystalline phase, which crystallized at $1050{ }^{\circ} \mathrm{C}$ with dendritic microstructure. This material had a greenish brown color and vitreous luster, and consisted of $60 \%$ crystalline phases (silicates) and $40 \%$ glassy phase. These characteristics also gave it a hardness of $5.44 \mathrm{GPa}(564.4 \mathrm{HV})$ or 6 (Mohs' scale), which compares with that of natural stones used as coating plates for buildings.

\section{Acknowledgment}

The authors acknowledge the financial support provided through the project TRISOLCOOLAB (ENE2010-20650-CO2-01-02), Ministerio de Ciencia e Innovación of the Spanish government for facilitating the presentation of this work in CRYSTALLIZATION 2012. Also, the authors thank FAPESP (2008/04368-4) for financial support of this project and FUNDUNESP (01090/2011-DFP) for financial aid. Dr. A. Leyva helped with English editing of the manuscript. 
S. R. Teixeira, A. E. Souza, C. L. Carvalho, V.C.S. Reynoso, M. Romero, J. Ma. Rincón, Characterization of a wollastonite glass-ceramic material prepared using sugar cane bagasse ash (SCBA) as one of the raw materials. Materials Characterization Volume 98, December 2014, Pages 209-214; doi:10.1016/j.matchar.2014.11.003

\section{References}

[1] W. Hölland, G. Beall, Glass-Ceramic Technology, American Ceramic Society, Westerville, $\mathrm{OH}, 2002$.

[2] W.A. Deer, R.A. Howie, J. Zussman, Introduction to the Rock Forming Minerals, Longman, Harlow, England, 1992. 140-143.

[3] R.D. Rawlings, J.P.Wu, A.R. Boccaccini, Glass-ceramics: their production fromwastes - a review, J. Mater. Sci. 41 (2006) 733-761.

[4] S.R. Teixeira, A.E. Souza, G.T.A. Santos, A.F.V. Pena, A.G. Miguel, Sugarcane bagasse ash as a potential quartz replacement in red ceramic, J. Am. Ceram. Soc. 91 (2008) 1883-1887.

[5] A.E. Souza, S.R. Texeira, G.T.A. Santos, F.B. Costa, E. Longo, Reuse of sugarcane bagasse ash (SCBA) to produce ceramic materials, J. Environ. Manag. 92 (2011) 2774-2780.

[6] N.U. Kockal, Properties and microstructure of porous ceramic bodies containing fly ash, J. Build. Phys. 35 (2011) 338-352.

[7] L.M. Schabbach, F. Andreola, L. Barbieri, I. Lancellotti, E. Karamanova, B. Ranguelov, A. Karamanov, Post-treated incinerator bottom ash as alternative raw material for ceramic manufacturing, J. Eur. Ceram. Soc. 32 (2012) 2843-2852.

[8] S.R. Teixeira, M. Romero, JMa Rincon, Crystallization of SiO2-CaO-Na2O glass using sugarcane bagasse ash as silica source, J. Am. Ceram. Soc. 93 (2010) 450-455.

[9] S.R. Teixeira, R.S. Magalhães, A. Arenales, A.E. Souza,M. Romero, JMa Rincón, Valorization of sugarcane bagasse ash: producing glass-ceramic materials, J. Environ. Manag. 134 (2014) 15-19.

[10] D.H. Vu, K.S. Wang, J.H. Chen, B.X. Nam, B.H. Bac, Glass-ceramic from mixtures of botton ash and fly ash, Waste Manag. 32 (2012) 2306-2314.

[11] S.D. Yoona, J.U. Leeb, Y.H. Yunb, H.S. Yang, Chemical durability of wollastonite glassceramics derived from waste glass and sludge bottom ash, J. Ceram. Process Res. 13 (2012) 52-55.

[12] S.R. Teixeira, A.E. Souza, A.E. Peña, A.F.V. Lima, A.G. Miguel, Use of charcoal and partially paralyzed biomaterial in fly ash to produce briquettes: sugarcane bagasse, in: $M$. 
S. R. Teixeira, A. E. Souza, C. L. Carvalho, V.C.S. Reynoso, M. Romero, J. Ma. Rincón, Characterization of a wollastonite glass-ceramic material prepared using sugar cane bagasse ash (SCBA) as one of the raw materials. Materials Characterization Volume 98, December 2014, Pages 209-214; doi:10.1016/j.matchar.2014.11.003

Manzanera (Ed.), Alternative Fuel, Rijeka, In Tech Open Access Publisher, Croatia, 2011, pp. 177-200.

[13] W. Chengyu, T. Ying, Calculation of the melting temperatures of silicate glasses, Glass Technol. 24 (1983) 278-282.

[14] A.C. Larson, R.B. Von Dreele, General structure analysis system (GSAS), Los Alamos National Laboratory Report — LAUR 86-748, Los Alamos NM, 2004.

[15] Encyclopædia Britannica Online. Mohs hardness Online Enc Britannica Inc., May 132014. (http://www.britannica.com/EBchecked/topic/387714/Mohs-hardness).

[16] A. Szymanski, J.M. Szymanski, Hardness, Estimation of Mineral, Rocks and Ceramic Materials, Polish Scientific Publishers, Warszawa, 1989.

[17] M. Romero, J Ma Rincon, A. Acosta, Effect of iron oxide content on the crystallization of a diopside glass-ceramic glaze, J. Eur. Ceram. Soc. 22 (2002) 883-890.

[18] M. Cocić, M. Logar, B.Matović, V. Poharc-Logar, Glass-ceramics obtained by the crystallization of basalt, Sci. Sinter. 42 (2010) 383-388.

[19] J.A. Lara Viera, J. Ibarra, L.M. Torres-Martínez, Análisis microestructural de un vitrocerámico empleando el método Rietveld, Ciencia UANL, VIII2005. 40-45.

[20] K. Yasukawa, Y. Terashi, A. Nakayama, Crystallinity analysis of glass-ceramics by the Rietveld method, J. Am. Ceram. Soc. 81 (1998) 2978-2982. 